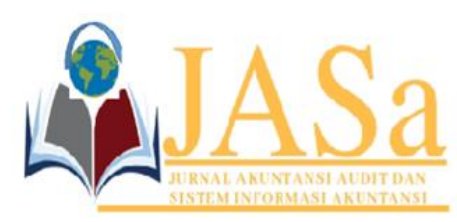

JASa (Jurnal Akuntansi, Audit dan Sistem Informasi Akuntansi)

Vol. 5 No.1/ April 2021

ISSN 2550-0732 print / ISSN 2655-8319 online

DOI;10.36555/jasa.v5i1.1505

\title{
THE EFFECT OF GOOD CORPORATE GOVERNANCE AND ACCOUNTING INFORMATION SYSTEMS ON THE QUALITY OF FINANCIAL STATEMENTS
}

\author{
Zahra Harlianti Sujana \\ Universitas Padjadjaran, Indonesia \\ Zahra19019@mail.unpad.ac.id
}

\begin{abstract}
This study aims to determine how the influence of good corporate governance and accounting information systems on the quality of financial reports at PT Pos Indonesia (Persero) Bandung City. The factors tested in this study are good corporate governance and accounting information systems as independent variables. Meanwhile, the quality of financial reports is the dependent variable. The research method used in this research is the verification method. The population in this study were employees of the finance department at PT.Pos Indonesia (Persero) Bandung. The sampling technique used in this study is a non-probability sampling technique with a saturated sampling method so that the sample in this study was 34 employees. The analytical method used in this study is multiple linear regression analysis using the Statistical Package for Social Sciences (SPSS) Ver.23.00. The results of research partially and simultaneously show that good corporate governance and accounting information systems affect the quality of financial reports at PT Pos Indonesia (Persero) Bandung City. Also, the magnitude of the influence of good corporate governance and accounting information systems in contributing to the influence of the quality of financial reports is $55.3 \%$.
\end{abstract}

Keywords: Good Corporate Governance, Accounting Information Systems, and Quality of Financial Statements.

\section{INTRODUCTION}

Stakeholders use financial reports as material for evaluating and predicting company performance (Nuraini, 2014). Financial reports as information will be useful if the information they contain is provided promptly to decision-makers before the information loses its capacity to influence decision making (Hanafi \& Abdul Halim, 2016, p. 35). The financial report is a very important tool for obtaining information regarding the financial position and results achieved by the company concerned, including information about the company's performance. Therefore, companies need to present quality financial reports by financial accounting standards (SAK). Statement of Financial Accounting Standards No.1 (2018: 86) states that the quality of financial statements is a qualitative characteristic of financial statements which is a characteristic that makes the information in these financial statements useful for users in making economic decisions (Ikatan Akuntan Indonesia, 2018, p. 86).

The problem regarding the quality of financial reports is now increasingly being discussed, the number of cases of poor quality financial reports in companies and local governments in Indonesia is still a hot issue that needs to be studied more deeply. One of the phenomena related to financial reports, which occurred in 2015, where the Supreme Audit Agency (BPK) reported problematic findings of fourteen State-Owned 


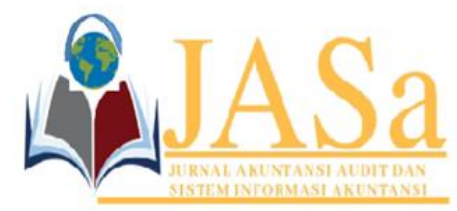

JASa (Jurnal Akuntansi, Audit dan Sistem Informasi Akuntansi)

Vol. 5 No.1/ April 2021

ISSN 2550-0732 print / ISSN 2655-8319 online

DOI;10.36555/jasa.v5i1.1505

Enterprises (BUMN) out of thirty-five companies proposed to receive State Capital Participation (PMN). Unfortunately, the quality of the financial reports of SOEs is still problematic, or they are said to have red report cards and have not completed significant findings and reports. The document states that 14 companies have not completed their recommendations based on BPK's findings. (BPK Findings: 14 StateOwned Enterprises That Receive Poor Performing State Equity) (Riyandi, 2015).

Therefore companies need to implement corporate governance. One of the companies that are obliged to implement good corporate governance is a company that is included in the state-owned company (BUMN). Good corporate governance has been implemented in almost all existing companies, both companies owned by the government (BUMN) and those owned by the private sector (Dwiridotjahjono, 2010). Regulation of the Minister for State-Owned Enterprises (BUMN) Number: PER-01MBU/2011 concerning the Implementation of Good Corporate Governance states that good corporate governance is the principles that underlie a process and mechanism for managing a company based on regulations. legislation and business ethics (Peraturan Menteri Badan Usaha Milik Negara, 2011).

Apart from the implementation of good corporate governance, information systems are also very important in supporting the quality of the company's financial reports. The purpose of accounting information systems is to assist the availability of information needed by all levels in the form of company management accountability reports, information systems provide information to support every decision taken by the leadership by established responsibilities, and information systems are needed to support the smooth operation of the company daily (Mardi, 2016, p. 5). The existence of an accounting information system is very helpful for companies in processing financial information to be more accurate and fast so that it can have an impact on improving the quality of financial reports. The accounting information system is a collection (integration) of sub-systems or components, both physical and non-physical, which are interconnected and harmoniously cooperate to process transaction data related to financial issues into financial information (Susanto, 2017, p. 72). One of the aims of implementing good corporate governance and accounting information systems is to improve the quality of the company's financial reports.

Regulation of the Minister of State-Owned Enterprises (BUMN) Number: PER01-MBU/2011 concerning the Implementation of Good Corporate Governance states that good corporate governance is the principles that underlie a process and mechanism for managing a company based on regulations legislation and business ethics (Peraturan Menteri Badan Usaha Milik Negara, 2011). Regulation of the State Minister for State-Owned Enterprises Number: PER-01/MBU/2011 concerning the Implementation of Good Corporate Governance in State-Owned Enterprises states that the principles of implementing good corporate governance are as follows:

1. Transparency

Namely openness in carrying out the decision-making process and openness in disclosing material and relevant information about the company.

2. Accountability

Namely, the clarity of the functions, implementation, and accountability of organs so that company management is carried out effectively. 


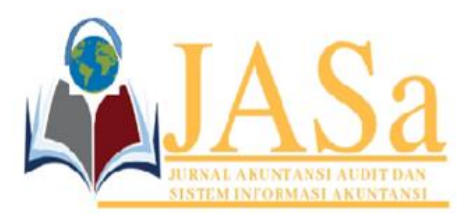

JASa (Jurnal Akuntansi, Audit dan Sistem Informasi Akuntansi)

Vol. 5 No.1/ April 2021

ISSN 2550-0732 print / ISSN 2655-8319 online

DOI;10.36555/jasa.v5i1.1505

3. Accountability

Namely, the suitability in the management of the company to the laws and regulations and sound corporate principles.

4. Independence

Namely, a situation where the company is managed professionally without conflict of interest and influence/pressure from any party that is by the laws and regulations and sound corporate principles.

5. Fairness

Namely justice and equality in fulfilling the rights of stakeholders that arise based on agreements and laws and regulations.

The accounting information system is a collection (integration) of sub-systems or components, both physical and non-physical, which are interconnected and harmoniously cooperate to process transaction data related to financial issues into financial information (Susanto, 2017, p. 72). According to Susanto (2017, p. 72) states that the components of the accounting information system are:

1. Hardware

Hardware is divided into several parts such as the input section, the processing or procedures and memory section, the output section, and the communications section.

2. Software

Software is divided into two major groups, namely system software, and application software. The system software is divided into several groups, namely operating systems, interpreters, and compilers. While application software is divided into several types of software depending on the application used.

3. Humans

Humans are people who own, build and operate accounting information systems. The term people here is not haphazard people in the true sense of being but people who have the competence (knowledge and skills or expertise) according to their level in information systems.

4. Procedure

Procedures are guidelines that must be followed and form based on an agreement with the determination and approval of the authorized management.

5. Database

Database in a broad sense is data that is in the company, while in a narrow sense, the database is data that is on the computer.

6. Network Communications

A communication network or what is called a data network is the use of electronic media to move data from one location or several locations to another.

Statement of Financial Accounting Standards No.1 (2018: 86) states that the

quality of financial statements is a qualitative characteristic of financial statements which is a characteristic that makes the information in these financial statements useful for users in making economic decisions (Ikatan Akuntan Indonesia, 2018, p. 86). Statement of Financial Accounting Standards No.1 (2018: 86) financial statements that 


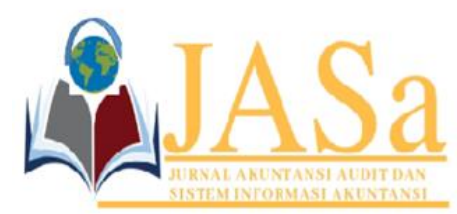

JASa (Jurnal Akuntansi, Audit dan Sistem Informasi Akuntansi)

Vol. 5 No.1/ April 2021

ISSN 2550-0732 print / ISSN 2655-8319 online

DOI;10.36555/jasa.v5i1.1505

are useful for informing users that there must be four main qualitative characteristics, namely as follows:

1. Can be understood

An important quality of the information contained in financial reports is that it is immediately understandable to users. For this purpose, users are assumed to have sufficient knowledge of economic and business activities, accounting, and a willingness to study information with reasonable diligence. However, complex information that should be included in financial statements cannot be released solely because the information is too difficult for certain users to understand.

2. Relevant

The information must be relevant to meet the needs of users in the decisionmaking process. The information has the quality of relevance if it can influence users' economic decisions by helping them evaluate past, present, or future events confirms, or correct the results of their past evaluations.

3. Reliability

The information must also be reliable, information has reliable quality if it is free from misleading, material, and can be relied upon by its use as a sincere or honest presenter of what it should be or can reasonably expect to be presented.

4. Comparable

Users should be able to compare the company's financial statements between periods to identify trends (trends) in financial position and performance. Users should also be able to compare financial statements between companies to evaluate their relative financial position. Therefore, measurement and presentation of the financial effects of transactions and other similar events must be carried out consistently for that entity, between the same entity's periods, and for different entities.

The implementation of good corporate governance will make the company carry out its operational activities based on the prevailing laws and regulations by sound governance. Therefore, the implementation of good corporate governance can support the quality of the financial statements produced by the company. Good corporate governance influences the quality of financial reports, where the more optimal implementation of good corporate governance, the better the quality of financial reports will be (Sari, 2018). The application of the principles of good corporate governance affects the quality of financial statements in companies, so if the principles of good corporate governance are applied properly, the better the quality of financial statements will be (Maryana et al., 2018).

$\mathrm{H} 1$ : Good corporate governance affects financial report quality

Information systems are also very important in supporting the quality of information systems reports are also very important in supporting the quality of company financial reports. The existence of an accounting information system helps companies in processing financial information to be more accurate and faster so that it can have an impact on improving the quality of financial reports. The accounting information system affects the quality of financial reports where the better the accounting information system, the better the quality of financial reports (Sari, 2018). The accounting information system has a strong relationship with the quality of financial 


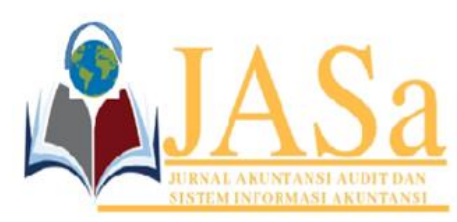

JASa (Jurnal Akuntansi, Audit dan Sistem Informasi Akuntansi)

Vol. 5 No.1/ April 2021

ISSN 2550-0732 print / ISSN 2655-8319 online

DOI;10.36555/jasa.v5i1.1505

reports. The accounting information system can explain its effect on the quality of financial reports. The accounting information system has a significant effect on the quality of financial reports (Zulfah et al., 2017).

H2: The accounting information system affects financial report quality

H3: Good corporate governance and accounting information systems affect good financial report quality

\section{METHODS}

The research methodology used in this research is verification. The population of this research is the employees of the finance department at PT. Pos Indonesia (Persero) Bandung City, amounting to 34 employees, while the sample in this study amounted to 34 employees. The types and sources of data used were primary data, while the data collection techniques used questionnaires. The independent variable is good corporate governance and accounting information system, while the dependent variable is the quality of financial reports. The data analysis used is multiple linear regression analysis using SPSS version 23.00.

RESULTS AND DISCUSSION

Tabel 1. Multiple Linear Regression

\begin{tabular}{cc}
\hline \multicolumn{1}{c}{ Variable } & Coefficient \\
\hline C & 0,332 \\
Good Corporate Governance & 0,404 \\
Accounting Information System & 0,407
\end{tabular}

Source: SPSS Output Results formed is:

Based on table 1 above shows that the regression equation model that is

$$
Y=0,332+0,404 X_{1}+0,407 X_{2}
$$

Based on the regression equation above, shows that good corporate governance and accounting information systems have a positive influence on the quality of financial reports.

Tabel 2. Partial Hypothesis Testing

\begin{tabular}{cccc}
\hline Variable & $\mathbf{t}$ & Prob & Result \\
\hline GCG & $2,693>2,040$ & $0,011<0,05$ & $\mathrm{H}_{1}$ Accepted \\
AIS & $2,680>2,040$ & $0,012<0,05$ & $\mathrm{H}_{2}$ Accepted \\
\hline
\end{tabular}

Source: SPSS Output Results 


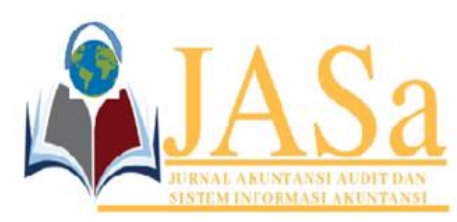

JASa (Jurnal Akuntansi, Audit dan Sistem Informasi Akuntansi)

Vol. 5 No.1/ April 2021

ISSN 2550-0732 print / ISSN 2655-8319 online

DOI;10.36555/jasa.v5i1.1505

Based on table 2. above partially shows that good corporate governance and accounting information systems affect the quality of financial reports.

Tabel 3. Simultaneous Hypothesis Testing

\begin{tabular}{cccc}
\hline Variable & F & Prob & Result \\
\cline { 1 - 1 } GCG & $19,198>3,30$ & $0,000<0,05$ & $\mathrm{H}_{3}$ Accepted \\
\cline { 1 - 1 } AIS & & & \\
\hline
\end{tabular}

Source: SPSS Output Results

Based on table 3. above, simultaneously shows that good corporate governance and accounting information systems affect the quality of financial reports

Tabel 4. Determination Coefficient Testing

\begin{tabular}{ccc}
\hline Information & Value & Percentage \\
\hline R-squared & 0,553 & $55,3 \%$ \\
\hline \multicolumn{2}{c}{ Source: SPSS Output Results }
\end{tabular}

Based on table 4. above shows that the magnitude of the influence of good corporate governance and accounting information systems affects the quality of financial reports by $55.3 \%$.

\section{Discussions}

\section{The Influence of Good Corporate Governance on Financial Report Quality}

The results showed that good corporate governance affects the quality of financial reports. The implementation of good corporate governance will make the company carry out its operational activities based on the prevailing laws and regulations by sound governance. Therefore, the implementation of good corporate governance can support the quality of the financial statements produced by the company. Good corporate governance influences the quality of financial reports, where the more optimal implementation of good corporate governance, the better the quality of financial reports will be (Sari, 2018). The application of the principles of good corporate governance affects the quality of financial statements in companies, so if the principles of good corporate governance are applied properly, the better the quality of financial statements will be (Maryana et al., 2018). The results of this study are in line with the results of previous studies conducted by Sari (2018) and Maryana et al., (2018). The results of his research show that good corporate governance affects the quality of financial statements.

\section{The Influence of Accounting Information Systems on Financial Report Quality}

The results showed that the accounting information system affected the quality of financial statements. Information systems are also very important in supporting the quality of information systems reports are also very important in supporting the quality of company financial reports. The existence of an accounting information system helps companies in processing financial information to be more accurate and faster so that it can have an impact on improving the quality of financial reports. The accounting 


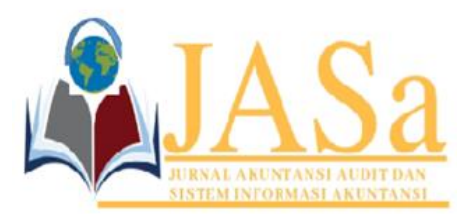

\author{
JASa (Jurnal Akuntansi, Audit dan Sistem Informasi Akuntansi) \\ Vol. 5 No.1/ April 2021 \\ ISSN 2550-0732 print / ISSN 2655-8319 online \\ DOI;10.36555/jasa.v5i1.1505
}

information system affects the quality of financial reports where the better the accounting information system, the better the quality of financial reports (Sari, 2018). The accounting information system has a strong relationship with the quality of financial reports. The accounting information system can explain its effect on the quality of financial reports. The accounting information system has a significant effect on the quality of financial statements (Zulfah et al., 2017). The results of this study are in line with the results of previous studies conducted by Sari (2018) and Zulfah et al., (2017). The results of his research indicate that the accounting information system affects the quality of financial statements.

\title{
CONCLUSIONS
}

Good corporate governance affects the quality of financial reports. Accounting information system affects the quality of financial reports. Good corporate governance and accounting information systems affect the quality of financial reports.

\section{REFERENCES}

Dwiridotjahjono, J. (2010). Penerapan Good Corporate Governance: Manfaat Dan

Tantangan Serta Kesempatan Bagi Perusahaan Publik Di Indonesia. Jurnal Administrasi Bisnis, Vol.5, No.(ISSN:0216-1249), hal. 101-112.

Hanafi, M. M., \& Abdul Halim. (2016). Analisis Laporan Keuangan (Edisi Tuju). UPP. AMP YKPN.

Ikatan Akuntan Indonesia. (2018). Pernyataan Standar Akuntansi Keuangan (Edisi Revi). Dewan Standar Akuntansi Keuangan.

Mardi. (2016). Sistem Informasi Akuntansi (Cetakan Kedua (ed.)). Ghalia Indonesia.

Maryana, H., Sukarmanto, E., \& Nurhayati. (2018). Pengaruh Penerapan PrinsipPrinsip Good Corporate Governance terhadap Kualitas Laporan Keuangan. Prosiding Akuntansi, Volume 4,(ISSN: 2460-6561).

Nuraini, M. (2014). Analisis faktor-faktor penentu persistensi laba. Universiras Diponegoro Semarang.

Peraturan Menteri Badan Usaha Milik Negara. (2011). Penerapan Tata Kelola Perusahaan yang Baik (Good Corporate Governance) Pada Badan Usaha Milik Negara. Menteri Badan Usaha Milik Negara.

Riyandi, S. (2015). BPK ungkap 14 BUMN penerima PMN punya rapor merah. Merdeka.Com. https://www.merdeka.com/uang/bpk-ungkap-14-bumn-penerimapmn-punya-rapor-merah.html

Sari, D. A. (2018). Kualitas Laporan Keuangan Dipengaruhi Oleh Penerapan Good Corporate Governance (GCG) dan Sistem Informasi Akuntansi (SIA). Jurnal Sistem Informasi Akuntansi.

Susanto, A. (2017). Sistem Informasi Akuntansi : Pemahaman Konsep Secara Terpadu (Cetakan Pe). Lingga Jaya.

Zulfah, I., Wahyuni, S., \& Arina Nurfaza. (2017). Pengaruh Sistem Informasi Akuntansi Terhadap Kualitas Laporan keuangan Pada SKPD Kabupaten Aceh Utara. Jurnal Akuntansi Dan Pembangunan, Volume 3 